\title{
Comparison of two mathematical models in the description of in situ degradability *
}

\section{Comparação de dois modelos matemáticos na descrição de degradabilidade in situ}

\author{
Taciana Villela Savian, ${ }^{* *}$ Joel Augusto Muniz, ${ }^{* *}$ Luiz Henrique de Aquino, ${ }^{* *}$ Daniel Furtado Ferreira ${ }^{* * *}$
}

\begin{abstract}
With the purpose of comparing the ruminal degradation models, proposed by Waldo et al. (1972) and Mertens and Loften (1980), the data of in situ degradability were employed. The experiment evaluated the potentially degradable residue of neutral detergent fiber (NDF) of grass Tifton 85 (Cynodon spp) submitted to twelve cutting ages (30,60, 90, 120, 150, 180, 210, 240, $270,300,330$ and 360 days), in a randomized block design with three replicates. At each cutting age, NDF degradation was investigated by utilizing nine incubation times $(0,3,6,12,24,48,72,96$ and 120 hours). The analysis was done by taking into account a strip experiment and the factors studied were cutting ages and the incubation times of the grass. Each plot comprised a non-lactating cow, with a permanent ruminal fistula. The quality of the fit of each model was evaluated by the respective fitted determination coefficients, test for 'lack of fit' and also the variances of the estimators of the parameters, by proposing expressions for estimate of the confidence interval for the parameters of the models. The results showed a better fit of the model by Waldo et al. (1972) to the data of neutral detergent fiber of grass Tifton 85.
\end{abstract}

Keywords: degradability model, fit quality, non-linear regression, colonization time.

\section{Resumo}

Com o objetivo de comparar os modelos de degradação ruminal, proposto por Waldo et al. (1972) e Mertens e Loften (1980), utilizaram-se os dados de um ensaio de degradabilidade in situ. O experimento avaliou o resíduo potencialmente degradável da fibra em detergente neutro (FDN) da gramínea Tifton 85 (Cynodon spp) submetida a 12 idades de corte (30, 60, 90, 120, 150, $180,210,240,270,300,330$ e 360 dias), em um delineamento em blocos casualizados com três repetições. Em cada idade de corte a degradação da FDN foi estudada utilizando nove tempos de incubação $(0,3,6,12,24,48,72,96$ e 120 horas). A análise foi feita considerando um experimento em faixas e os fatores estudados foram as idades de corte e os tempos de incubação da gramínea. Cada parcela foi constituída por uma vaca, não-lactante, com fístula ruminal permanente. A qualidade do ajuste de cada modelo foi avaliada pelos respectivos coeficientes de determinação ajustados, teste para 'falta de ajustamento' e obtiveram-se também as variâncias dos estimadores dos parâmetros, propondo-se expressões para a estimação do intervalo de confiança para os parâmetros dos modelos. Os resultados mostraram um melhor ajuste do modelo de Waldo et al. (1972) aos dados de fibra em detergente neutro da gramínea Tifton 85.

Palavras-chave: modelo de degradabilidade, qualidade de ajuste, regressão não-linear, tempo de colonização.

\section{Introduction}

Information on quantitative knowledge of the factors which control the digestive processes have directed the investigation in the field of Ruminant Nutrition, aiming to reach the best performances for the herds, thus the handling of the diets has focused as a way to increase animal production.

The "in vitro and in situ" trials are reliable techniques to supply estimates of the nutritive value of ruminant feeds. Nevertheless, the ideal would be a method which would be able to estimate with a reasonable accuracy in vivo digestibility, without the need of conducting a conventional trial, since it is extremely tiring and limited in its use, when there is a need for fast responses.

The in situ degradability technique has been adopted by the AFRC (1992) as a standard method of characterization of the ruminal degradability of nitrogen, being able to be utilized to report the characteristic degradation of dietary fibers (Aerts et

\footnotetext{
*Work developed by the former author, CNPq scientific initiation grantee.

${ }^{* *}$ Graduate student in Agronomy / Statistics and Agricultural Experimentation. Department of Exact Sciences Federal University of Lavras, Zip Code: 37200-000. Lavras, MG, e-mail: tacivs@bol.com.br.

${ }^{* \star *}$ Professors of the area of Statistics, Department of Exact Sciences, Federal University of Lavras, Lavras, MG.
} 
al., 1977; Navaratree, Ibrahin and Shiere, 1990) and protein (Crawford et al., 1978; Stern e Satter, 1984; Poos-Floyd, Klopfenstein and Britton, 1985). The use of this technique has the advantage to provide a fast and simple estimate of nutrient degradation in the rumen, in addition to enabling the accompanying of this over time (Mehrez e Orskov, 1977).

Evaluating a possible relationship between a dependent variable and an independent variable is a common task in statistic analyses and may be done through regression models, which according to Draper and Smith (1998), can be linear, linearizable and non-linear. The studies of growth of animal and plants, as well as the nutrient degradation studies over time are reported by non-linear, presenting some difficulties in the process of estimating parameters.

The models developed to report the digestive events occurring in the rumen are numerous; some approach the quantification of total or partial processes of ruminal digestion and others are complex models of simulation which regard rumen in a global way. At present, two sorts of interest are realized which demand the evaluation of digestibility of a forage plant. The former is the need to compare different forage plants, by taking into account that the most digestible will show better economical/productive return by the animals which consume it, and the latter is the formulation of mechanistic models which express progressively and truly the dynamic phenomenon of digestion considering the circumstantial factors inherent to feeds such as composition, amount, feeding frequency and son on.

The option for one of the above-reported interest will make the choice of the mathematical model to be chased easy. The first interest recorded utilizes dynamic models as related with time of permanence of feed in the rumen and estimates its maximum degradation potential, characteristics which may be utilized for evaluation of the value of that feed. The second interest, generally, defines compartmental, mechanistic models in the sense of identifying biological compartments where feed undergoes sequentially modifications foreseen in the model.

According to Mertens (1993) the first evaluations of digestion processes, which depend on retention time, were qualitative and based upon the visual interpretation of digestion curves, these being of difficult description, since these curves showed non-linear behaviors. The author reports that Waldo was the first to suggest a conceptual innovation, which has suited as a basis for a new view of the mathematical models related with digestion kinetics, with which a real quantification of the fact was intended.

The model by Waldo et al. (1972) who reports the degradability technique for evaluation of rumen-incubated nutrients is given by the following equation:

$R(t)=D\left(e^{-c t}\right)+I \quad$ onde $:$ where

$R(t)$ is the residue after incubation in the rumen in time ' $t$ '; ' $D$ ' is the degradable fraction I (\%); 'c' is the constant degradation rate; ' $t$ ' incubation time in hours and $I$ is the insoluble and non-degradable fraction.

It is known that for digestion to process, the microorganisms must penetrate the resistant barriers of the surface of particles of feeds to reach their preferred substrates and the extent to which microorganisms fix and penetrate these physical barriers is reflected in colonization time which characterizes the ruminal digestion of several feeds.

Mertens and Loften (1980) suggested the inclusion of parameter L, 'lag time' or colonization time, for the estimates of the parameters of the first-order model of Waldo et al. (1972) for in situ degradability of NDF, DM and N, as indicated in the equation:

$R(t)=\left\{\begin{array}{c}D_{0}+I \quad \text { para } 0 \leq t \leq L \\ D_{0} e^{-c(t-L)}+I \text { para } t>L\end{array} \quad\right.$ where

$D_{0}$ is the degradable fraction ( $t$ d" $L, D_{0}=R-$ ), the parameters $R(t)$, c e t , were defined in the previous equation.

The authors also suggested for the calculation of 'lag time' the equation:

$L=\frac{\ln D_{0}-\ln D_{i}}{-c} \quad$ where

$\ln D_{i}$ is the intercept of equation $\ln (R-I)$ with the axis of the ordinates; $D_{0}$ is the degradable potential residue in time $\mathrm{t}=0$.

The matter is summed up in how reliable the estimates obtained by the fit of degradation data of these models are, and what would be the real need to employ more complex models, with higher number of parameters and, hence, greater flexibility of fit to the data of nutrient degradability.

\section{Methodology}

The data for analysis were obtained in Reis (2000), where grass Tifton 85 (Cynodon spp) was submitted to twelve cutting ages $(30,60,90,120,150,180,210,240,270,300,330$ and 360 days), by making use of a randomized block design with three replicates, and at each age, degradation was evaluated in nine incubation times $(0,3,6,12,24,48,72,96$ and 120 hours). The potentially degradable residue of neutral detergent fiber (NDF) of grass was analyzed. The statistical analysis was done by considering a strip experiment, according to Gill (1987), since the factor time, due to its nature, was given no randomization.

The statistical model was the following:

$y_{i j k}=\mu+\delta_{i}+a_{j}+\delta a_{i j}+\beta_{k}+a \beta_{j k}+\delta \beta_{i k}+E_{i j k}$

so: $\mu$ a constant associated with all the observations;

$\delta_{i}$ the effect of cutting age $\mathrm{i}$, with $\mathrm{i}=1, \ldots, 12$;

$a_{j}$ the effect of animal j, with j =1,2, 3;

$\delta a_{i j}$ the effect of the interaction of the i-th cutting age with the $j$-th animal, regarded as error (a), with a normal distribution of mean zero and variance $\sigma_{a}^{2}$; $\beta_{k}$ the effect of incubation time $\mathrm{k}$, with $\mathrm{k}=1, \ldots, 9$; $a \beta_{j k}$ the effect of the interaction of the o k-th incubation time with the $j$-th animal, regarded as error(b), with a normal distribution of mean zero and variance $\sigma_{b}^{2}$; $\delta \beta_{i k}$ the effect of the interaction of the k-th incubation time with the i-th cutting age; 
$E_{i j k}$ regarded as error(c), with a normal distribution of mean zero and variance $\sigma^{2}$.

The data were submitted to the analysis of regression by utilizing routines of the software Statistical Analysis System (SAS, 1991), using the non linear procedure of the method of Gauss-Newton (Neter, Wasserman and Kutner, 1985) to proceed the estimate of parameters 'D', 'l', 'C' e 'L', of the models of Waldo et al (1972) - M1 and Mertens and Loften (1980) - M2, considering a initial estimate and seeking to minimize the sum of squares of errors. In estimating the parameters, the iterative process was utilized till the improvement in the fit of data was negligible.

According to Souza (1998), on the contrary of the linear model, determination of the estimate of the parameters may be problematic in the non-linear case. The success in the utilization of Gauss-Newton's algorithm is going to depend upon the appropriate choice of the response function and upon good initial values. Although, there are some general orientations to the determination of initial values, the choice procedure is a procedure decided by the researcher. A number of alternatives for determination of those values are presented in Draper and Smith (1998) and Gallant (1987).

In fitting the model by means of the NLIN procedure of SAS, the asymptotic estimate of the variance and covariance matrix of the estimates of the parameters was obtained, according to Souza (1998), considering a strip experiment. The matrix terms are expressed by:

$\left[\begin{array}{ccc}S E_{a}^{2} & \hat{\rho}_{a b} S E_{a} S E_{b} & \hat{\rho}_{a c} S E_{a} S E_{c} \\ \hat{\rho}_{a b} S E_{a} S E_{b} & S E_{b}^{2} & \hat{\rho}_{b c} S E_{b} S E_{c} \\ \hat{\rho}_{a c} S E_{a} S E_{c} & \hat{\rho}_{b c} S E_{b} S E_{c} & S E_{c}^{2}\end{array}\right] x \frac{Q M E_{c o m b i n e d}}{r Q M D R}$

where: $\mathrm{SE}_{\mathrm{a}}, \mathrm{SE}_{\mathrm{b}}, \mathrm{SE}_{\mathrm{c}}$ are the standard errors of the estimates of parameters $a, b$, and c considering only the nine incubation times; $\hat{\rho}_{a b}, \hat{\rho}_{a c}$ and $\hat{\rho}_{b c}$ are the asymptotic correlation coefficients among the parameters; QMDR is the mean square of the regression deviation based upon means; $r$ is the number of animals where the incubation times were evaluated; $Q M E_{\text {combined }}$ is the mean square of error obtained by a linear combination of the mean squares of errors $b$ and $c$ of the analysis of variance, according to Satterthwaite (1946).

The main diagonal of the covariances matrix furnishes the expressions of variances adequate to the calculation of the asymptotic confidence intervals:

$$
\begin{aligned}
& \hat{V}(\hat{a})=S E_{a}^{2} \frac{Q M E_{\text {combined }}}{r Q M D R} \\
& \hat{V}(\hat{b})=S E_{b}^{2} \frac{Q M E_{\text {combined }}}{r Q M D R} \\
& \hat{V}(\hat{c})=S E_{c}^{2} \frac{Q M E_{\text {combined }}}{r Q M D R}
\end{aligned}
$$

With the goal of evaluating the goodness of the models were considered the fitted determination coefficients, $F$ test for 'lack of fit' presented by Hoffmann and Vieira (1998); and of the asymptotic confidence intervals for the estimates of the parameters for the two models, at each cutting age.

\section{Results and discussion}

The cutting age of the grass influenced the NDF degradation of Tifton $85(P<0.01)$ and the results of the analysis of variance are presented in Table 1.

Table 1: Analyses of variance of the NDF degradation for the models of Waldo et al. (M1) and Mertens and Loften (M2), of grass Tifton 85 , considering a strip experiment

\begin{tabular}{lcccc}
\hline \multirow{2}{*}{$\begin{array}{c}\text { Sources of } \\
\text { variation }\end{array}$} & \multicolumn{3}{c}{ Tifton85 } \\
\cline { 2 - 5 } & $\mathrm{GL}-1$ & \multicolumn{3}{c}{$\mathrm{M}-2$} \\
\hline & $\mathrm{G}$ & $\mathrm{QM}$ & $\mathrm{GL}$ & $\mathrm{QM}$ \\
\hline Animal $(\mathrm{A})$ & 2 & $2080,1050^{* *}$ & 2 & $2136.4163^{* *}$ \\
Age (I) & 11 & $2255.9148^{* *}$ & 11 & $2347.2542^{* *}$ \\
Error (a) & 22 & 337.1578 & 22 & $316.8002^{* * *}$ \\
Time (T) & 8 & $10241.4337^{* *}$ & 7 & $8793.1778^{* *}$ \\
Error (b) & 16 & 31.8786 & 14 & $22.1256^{* *}$ \\
I x T & 88 & $93.3759^{* *}$ & 77 & $86.0688^{* *}$ \\
Error (c) & 176 & 21.6046 & 154 & 21.7393 \\
\hline CV 1 (\%) & 28.26 & & 28.62 \\
CV 2 (\%) & 8.69 & & 7.56 \\
CV 3 (\%) & 7.15 & & 7.50 \\
\hline C P
\end{tabular}

** $P<0.01$

The significant interaction $(P<0.01)$ shows that the cutting ages of the grass differ relative to the incubation times, and thus, it was opted by its unfolding, doing the fit of models M1 (Table2) and M2 (Table 3) for each cutting age.

The results presented in tables 2 and 3 show that $F$ test for the regression deviation was not significant $(P>0.05)$ at all cutting ages, both for the model of Waldo et al. (M1) and for the model of Mertens and Loften (M2), showing that both are appropriate in reporting neutral detergent fiber degradation of grass Tifton 85 and that the medium squares of the regression deviations estimate the respective residual variances.

In Tables 2 and 3 are also presented the results of the determination coefficients fitted to the models of Waldo et al. (M1) and Mertens and Loften (M2) respectively. The value of the determination coefficient depends upon the number of observations, tending to increase when the number of observations decreases. To overcome this drawback, Hoffmann and Vieira (1998) defined the determination coefficient fitted to this number of observations. Sampaio (1997) further reports that the great number of collections, although physiologically has a greater biologic meaning, interferes in the digestive process by the constant removal of the nylon bag out of the rumen. The results in tables 2 and 3 , show that in fitting the model of Mertens and Loftens (M2) to the data, there was a decrease in the determination coefficients fitted to most of the cutting ages, excepting the cutting of the grass at $60 \mathrm{e}$ 330 days old.

In Table 4, the estimates of the parameters of the models of Waldo et al. (M1) and Mertens and Loften (M2) at each cutting age are viewed as well as the estimate of the variance of the estimates of these parameters, adequate to the calculation of the asymptotic confidence intervals. The fit of the model of Mertens and Loften (M2) determined greater estimates of variance of the estimate of the potentially degradable residues (parameter D) in most of ages, except for cutting at 30, 120 
Table 2: Analysis of variance for neutral detergent fiber (NDF), studying the effect of time within each cutting age, for the model of Waldo et al. (M1)

\begin{tabular}{|c|c|c|c|c|c|c|c|}
\hline \multirow{2}{*}{ Source of variation } & \multirow{2}{*}{$\mathrm{GL}$} & \multicolumn{6}{|c|}{ QM } \\
\hline & & 30 days & $\mathrm{R}_{\mathrm{aj}}^{2}$ & 60 days & $\mathrm{R}_{\mathrm{aj}}^{2}$ & 90 days & $R_{a j}^{2}$ \\
\hline Time/ Cutting Age & 8 & 705.5578 & & 289.2791 & & 653.7791 & \\
\hline Non-corrected model & 3 & 31456.3138 & & 57666.7123 & & 42421.5022 & \\
\hline Constant (a) & 1 & 88785.7640 & & 170720.6482 & & 122251.4247 & \\
\hline Corrected model & 2 & 2791.5887 & 98.82 & 1139.7444 & 98.38 & 2506.5410 & 95.50 \\
\hline Deviation of regression & 6 & $10.0875^{\mathrm{ns}}$ & & $5.7786^{\mathrm{ns}}$ & & $36.1613^{\mathrm{ns}}$ & \\
\hline \multirow[t]{2}{*}{ Combined error } & 189 & 22.4607 & & 22.4607 & & 22.4607 & \\
\hline & & 120 days & $R_{\text {aj }}^{2}$ & 150 days & $R_{\text {aj }}^{2}$ & 180 days & $R_{a j}^{2}$ \\
\hline Time/ Cutting Age & 8 & 656.2946 & & 535.5542 & & 454.5625 & \\
\hline Non-corrected model o & 3 & 46229.3323 & & 51107.0248 & & 48675.3423 & \\
\hline Constant (a) & 1 & 133470.0070 & & 149061.3668 & & 142465.2078 & \\
\hline Corrected model & 2 & 2608.9949 & 99.33 & 2129.8538 & 99.37 & 1780.4095 & 97.75 \\
\hline Regression deviation & 6 & $5.4644^{\mathrm{ns}}$ & & $4.1102^{\mathrm{ns}}$ & & $12.6711^{\mathrm{ns}}$ & \\
\hline \multirow[t]{2}{*}{ Combined error } & 189 & 22.4607 & & 22.4607 & & 22.4607 & \\
\hline & & 210 days & $R_{a j}^{2}$ & 240 days & $\mathrm{R}_{\mathrm{aj}}^{2}$ & 270 days & $\mathrm{R}_{\mathrm{aj}}^{2}$ \\
\hline Time/ Cutting Age & 8 & 1723.2567 & & 2244.4848 & & 1471.6421 & \\
\hline Non-corrected model & 3 & 35087.6764 & & 39152.5506 & & 25172.1671 & \\
\hline Constant (a) & 1 & 91598.9352 & & 99645.0814 & & 63813.9019 & \\
\hline Corrected Model & 2 & 6832.0471 & 99.03 & 8906.2852 & 99.13 & 5851.2997 & 99.35 \\
\hline Regression Model & 6 & $20.3702^{\text {ns }}$ & & $24.0004^{\mathrm{ns}}$ & & $11.7604^{\mathrm{ns}}$ & \\
\hline \multirow[t]{2}{*}{ Combined error } & 189 & 22.4607 & & 22.4607 & & 22.4607 & \\
\hline & & 300 days & $R_{\text {aj }}^{2}$ & 330 days & $\mathrm{R}_{\text {aj }}^{2}$ & 360 days & $R_{a j}^{2}$ \\
\hline Time/ Cutting Age & 8 & 859.3705 & & 1125.0248 & & 549.7542 & \\
\hline Non-corrected model & 3 & 33482.9001 & & 34178.0844 & & 49466.3937 & \\
\hline Constant (a) & 1 & 93672.8186 & & 93586.5402 & & 144011.2430 & \\
\hline Corrected Model & 2 & 3387.9409 & 98.44 & 4473.8565 & 99.37 & 2193.9691 & 99.75 \\
\hline Regression deviation & 6 & $16.5906^{\mathrm{ns}}$ & & $8.6871^{\mathrm{ns}}$ & & $1.6086^{\mathrm{ns}}$ & \\
\hline Combined error & 189 & 22.4607 & & 22.4607 & & 22.4607 & \\
\hline
\end{tabular}

ns non significant $(P>0.05)$

and 240 days, but for the estimate of the insoluble and nondegradable residue (parameter I), considering the same model, smaller estimates of the variance occurred for the cutting at 30,240 and 330 days.

The model of Mertens and Loften (M2) showed sensitivity in detecting time of particle colonization (lag time) only at the cutting ages of 240 and 330 days, these estimates being of 1.02 and 1.15 hours, respectively.

According to Feitosa (1999) this lack of sensitivity of the model in the detection of lag time was also observed by Vieira (1995) standing out the need for elucidation as to the correct use of this parameter. According to Sampaio (1997) only the period comprised between lag time and a reasonably long incubation time should be submitted to modeling and that this interval would be from 6 to 96 hours for forage plants and from 4 to 64 hours for concentrates or most rapidly degrading industrial residues.

Sampaio (1997) concluded also that considering this restrict period where degradation is taking place on the incubated material, the model to be defined, generally non-linear, should contain the least possible number of parameters. 
Table 3: Analysis of variance for neutral detergent fiber (NDF), studying the effect of time within each cutting age for the model of Mertens and Loften (M2).

\begin{tabular}{|c|c|c|c|c|c|c|c|}
\hline \multirow{2}{*}{ Source of variation } & \multirow{2}{*}{$\mathrm{GL}$} & \multicolumn{6}{|c|}{ QM } \\
\hline & & 30 days & $R_{a j}^{2}$ & 60 days & $R_{\text {aj }}^{2}$ & 90 days & $R_{\text {aj }}^{2}$ \\
\hline Time/ Cutting Age & 7 & 542,8926 & & 243.1339 & & 547.8295 & \\
\hline Non-corrected model & 3 & 24946.5749 & & 49026.0634 & & 34752.9223 & \\
\hline Constant (a) & 1 & 71083.4218 & & 145393.8591 & & 100614.5250 & \\
\hline Corrected model & 2 & 1878.1514 & 98.73 & 842.1656 & 98.86 & 1822.1208 & 94.56 \\
\hline Regression model & 5 & $8.7025^{\mathrm{ns}}$ & & $3.5210^{\text {ns }}$ & & $38.1450^{\text {ns }}$ & \\
\hline \multirow[t]{2}{*}{ Combined Error } & 168 & 21.7715 & & 21.7715 & & 21.7715 & \\
\hline & & 120 days & $R_{\text {aj }}^{2}$ & 150 days & $R_{\text {aj }}^{2}$ & 180 days & $R_{\text {aj }}^{2}$ \\
\hline Time/ Cutting Age & 7 & 586.5603 & & 476.9282 & & 414.6565 & \\
\hline Non-corrected model & 3 & 38357.2498 & & 42818.6866 & & 41039.2054 & \\
\hline Constant (a) & 1 & 110998.3587 & & 125141.4458 & & 120290.5233 & \\
\hline Corrected model & 2 & 2036.6953 & 99.13 & 1657.3070 & 99.21 & 1413.5464 & 97.15 \\
\hline $\begin{array}{l}\text { Regression model } \\
\text { Regression model }\end{array}$ & 5 & $6.5526^{\mathrm{ns}}$ & & $4.8111^{\mathrm{ns}}$ & & $15.5968^{\text {ns }}$ & \\
\hline \multirow[t]{2}{*}{ Combined error } & 168 & 21.7715 & & 21.7715 & & 21.7715 & \\
\hline & & 210 days & $R_{\text {aj }}^{2}$ & 240 days & $R_{\text {aj }}^{2}$ & 270 days & $R_{\text {aj }}^{2}$ \\
\hline Time/ Cutting age & 7 & 1481.8287 & & 2121.3162 & & 1186.6985 & \\
\hline Non-corrected model & 3 & 26982.0684 & & 30863.5431 & & 18672.3355 & \\
\hline Constant (a) & 1 & 70686.8679 & & 77858.9961 & & 47760.8007 & \\
\hline Corrected model & 2 & 5129.6687 & 98.81 & 7365.8166 & 96.47 & 4128.1028 & 99.33 \\
\hline Regression model & 5 & $22.7615^{\mathrm{ns}}$ & & $23.5586^{\mathrm{ns}}$ & & $10.1772^{\mathrm{ns}}$ & \\
\hline \multirow[t]{2}{*}{ Combined error } & 168 & 21.7715 & & 21.7715 & & 21.7715 & \\
\hline & & 300 days & $R_{a j}^{2}$ & 330 days & $R_{a j}^{2}$ & 360 days & $R_{a j}^{2}$ \\
\hline Time/ Cutting Age & 7 & 662.1616 & & 1001.9613 & & 473.9668 & \\
\hline Non corrected model & 3 & 26320.9457 & & 27275.1720 & & 41200.2978 & \\
\hline Constant (a) & 1 & 74409.6718 & & 74839.1848 & & 120291.2951 & \\
\hline Corrected model & 2 & 2276.5826 & 98.06 & 3493.1655 & 99.57 & 1654.7992 & 99.73 \\
\hline Regression model & 5 & $16.5255^{\text {ns }}$ & & $5.4477^{\mathrm{ns}}$ & & $1.5969^{\mathrm{ns}}$ & \\
\hline Combined error & 168 & 21.7715 & & 21.7715 & & 21.7715 & \\
\hline
\end{tabular}

ns non significant $\quad(P>0.05)$

\section{Conclusions}

The indicators of quality, although have shown a good fit of the models of Waldo et al. (1972) and Mertens and Loften (1980), to the data of the experiment, a decrease in the determination coefficient of the variance of the estimate of the parameters was found in fitting the model of Mertens and Loften (1980) in most of cutting ages.
The model of Mertens and Loften (1980) showed no sensitivity in the detection of colonization time (lag time) for most cutting ages studied and when it was estimated, it proved inferior to that found in the literature, stressing the need for elucidation concerning the correct use of this parameter. 
Table 4: Estimate of the parameters of the model of Waldo et al. (M1) and Mertens and Loften (M2), with the respective estimates of variance

\begin{tabular}{|c|c|c|c|c|c|c|c|}
\hline \multirow{2}{*}{\multicolumn{2}{|c|}{$\begin{array}{l}\text { Cutting age } \\
\text { (days) }\end{array}$}} & \multicolumn{2}{|c|}{ Estimates (Variance) } & \multirow{2}{*}{\multicolumn{2}{|c|}{$\begin{array}{l}\text { Cutting } \\
\text { Age } \\
\text { (days) }\end{array}$}} & \multicolumn{2}{|c|}{ Estimates (Variance) } \\
\hline & & M1 & M2 & & & M1 & M2 \\
\hline & $\mathrm{D}$ & $38.3553(1.987896)$ & 34.3914 (0.854969) & & $\mathrm{D}$ & 62.6220 (3.070597) & 62.3568 (3.486102) \\
\hline \multirow[t]{4}{*}{30} & $\mathrm{C}$ & 0.0409 (0.000022) & $0.0276(0.000007)$ & 210 & $\mathrm{C}$ & $0.0262(0.000005)$ & $0.0246(0.000006)$ \\
\hline & 1 & 40.8284 (1.284988) & $38.6818(0.780087)$ & & 1 & $26.2343(3.310515)$ & $25.3461(4.245564)$ \\
\hline & $\mathrm{L}$ & & ----- & & $\mathrm{L}$ & & ----- \\
\hline & $\mathrm{D}$ & 27.6536 (7.352469) & 28.6567 (16.961323) & & $\mathrm{D}$ & 77.4753 (7.528495) & 77.4319 (5.770819) \\
\hline \multirow[t]{4}{*}{60} & $\mathrm{C}$ & $0.0189(0.000024)$ & $0.0149(0.000027)$ & 240 & $\mathrm{C}$ & $0.0187(0.000003)$ & $0.0202(0.000004)$ \\
\hline & 1 & 63.5437 (8.823736) & $61.1852(21.723679)$ & & 1 & $15.8803(9.035844)$ & $17.5325(7.747532)$ \\
\hline & $\mathrm{L}$ & & ----- & & $\mathrm{L}$ & & 1.0177 \\
\hline & $\mathrm{D}$ & 38.3622 (3.493391) & 38.9501 (6.713096) & & $\mathrm{D}$ & $56.0101(2.139839)$ & $54.8631(2.660594)$ \\
\hline \multirow[t]{4}{*}{90} & C & $0.0247(0.000014)$ & $0.0192(0.000015)$ & 270 & $\mathrm{C}$ & $0.0346(0.000009)$ & $0.0317(0.000010)$ \\
\hline & 1 & 47.2174 (3.915197) & $44.4822(9.038595)$ & & 1 & 22.8749 (1.733082) & $22.1400(2.214380)$ \\
\hline & $\mathrm{L}$ & & ----- & & $\mathrm{L}$ & & ----- \\
\hline & $\mathrm{D}$ & 39.7891 (4.217638) & 39.7850 (4.173521) & & $\mathrm{D}$ & 42.2221 (1.976852) & $40.7930(2.694033)$ \\
\hline \multirow[t]{4}{*}{120} & $\mathrm{C}$ & $0.0228(0.000012)$ & $0.0227(0.000015)$ & 300 & $\mathrm{C}$ & $0.0422(0.000019)$ & $0.0367(0.000023)$ \\
\hline & I & 48.8711 (4.897822) & $48.8184(5.395706)$ & & 1 & 40.9485 (1.222535) & 40.1651 (1.632288) \\
\hline & $\mathrm{L}$ & & ----- & & $\mathrm{L}$ & & ----- \\
\hline & $\mathrm{D}$ & 36.3898 (4.840462) & $36.3864(5.071860)$ & & $\mathrm{D}$ & $49.0897(2.187366)$ & $50.5547(2.707171)$ \\
\hline \multirow[t]{4}{*}{150} & $\mathrm{C}$ & $0.0217(0.000015)$ & $0.0211(0.000017)$ & 330 & $\mathrm{C}$ & $0.0336(0.000011)$ & $0.0371(0.000015)$ \\
\hline & 1 & $54.3182(5.709592)$ & $54.0502(6.752165)$ & & 1 & $36.0620(1.837148)$ & $36.7295(1.595936)$ \\
\hline & $\mathrm{L}$ & & ----- & & $\mathrm{L}$ & & 1.1464 \\
\hline & $\mathrm{D}$ & 34.5817 (7.395547) & 34.6432 (7.415862) & & $\mathrm{D}$ & 35.4857 (3.070362) & 35.3225 (3.354114) \\
\hline \multirow[t]{3}{*}{180} & C & $0.0188(0.000016)$ & $0.0185(0.000018)$ & 360 & $\mathrm{C}$ & $0.0262(0.000017)$ & $0.0252(0.000020)$ \\
\hline & 1 & $52.6510(8.875696)$ & 52.4623 (9.968649) & & 1 & 54.8941 (3.309823) & $54.5752(4.003351)$ \\
\hline & $\mathrm{L}$ & & ----- & & $\mathrm{L}$ & & ----- \\
\hline
\end{tabular}

\section{References}

AERTS, J.W; De BRABANDER, D.L; COTTYN, B.G. et al. Comparison of laboratory methods for predicting of the organic matter digestibility of forages. Animal Feed Science and Technology, Amsterdam, v. 2, p. 337-349, 1997.

AGRICULTURAL AND FOOD RESERCH COUNCIL (AFRC). Technical Committee on responses to nutrients: Nutritive requirements of ruminant animals: protein. Nutrition Abstracts and Reviews: series B, London, v. 62, n. 9, p. 65-71, Sept. 1992.

CRAWFORD, R.J.; HOOVER, W.H.Jr; SNIFFEN, C.J. et al. Degradation of foodstuff nitrogen in the rumen vs. Nitrogen solubility in three solvents. Journal of Animal Science, Champaign, v. 46, n. 6, p. 1768-1775, May, 1978.

DRAPER,N. R.; SMITH, H. Applied regression analysis. 3. ed. New York: John Wiley \& Sons, 1998. 706p.

FEITOSA, J. V. Ensaios de degradabilidade in situ: uma abordagem estatística. 1999. 117 p. Dissertação (Mestrado) - Universidade de São Paulo, Jaboticabal, 1999.
GALLANT, A. R. Nonlinear statistical models. New York: John Wiley \& Sons, $1987.610 \mathrm{p}$.

GILL, J.L. Design and analysis of experiments in the animal and medical sciences. lowa State University Press, Ames, lowa, v. 1, 1987. 411 p. HOFFMANN, R.; VIEIRA, S. Análise de regressão: uma introdução à econometria. 3. ed. São Paulo: HUCITEC, 1998. 379 p.

MEHREZ, A. Z.; ORSKOV, E. R. A study of the artificial fibre bag technique for determining the digestibility of feeds in the rumen. Journal of Agricultural Science, Cambridge, v. 88,n. 3, p. 645-650, 1977.

MERTENS, D. R., LOFTEN, J. R. The effects of starch on forage fiber digestion kinetics in vitro. J. Dairy Sci., v. 63, p. 1437-1446, 1980.

MERTENS, D. R. Rate and extent of digestion. Chap. II. In: FORBES, J. M., FRANCE, J. (Ed.) Qualitative aspects of ruminant digestion and metabolism. Wallingford, UK: Cambridge University Press, 1993. p. 13-51.

NAVARATRE, H.U.R.G.; IBRAHIM, M.N.M.; SHIERE, J.B. Comparison of four techniques for predicting digestibility of tropical feeds. Animal Feed Science and Technology, Amsterdam, v. 29, n. 1, p. 209-221, 1990. 
NETER, J.; WASSERMAN, W.; KUTNER, M. H. Linear statistical models: regression, analysis of variance, and experimental design. 2. ed. USA: Richard D. Irwin, 1985. $1125 \mathrm{p}$.

POOS-FLOYD, M.; KLOPFENSTEIN, T.; BRITTON, R.A. Evaluation of laboratory techniques for predicting ruminal protein degradation. Journal of Dairy Science, Champaign, v. 68, n. 4, p. 829-839, Apr. 1985.

REIS, S. T. dos. Valor nutricional de gramíneas tropicais em diferentes idades de corte. 2000. 99 p. Dissertação (Mestrado) - Universidade Federal de Lavras, Lavras, MG, 2000.

SAMPAIO, I. B. M. Métodos estatísticos aplicados à determinação de digestibilidade in situ. In: Simpósio Internacional de Digestibilidade em Ruminantes, 1997, Lavras: UFLA - FAEPE, 1997. p. 327.

SATTERTHWAITE, F. E. An approximate distribution of variance components. Biometrics, v. 2, n. 3, p. 110-114, 1946.
SOUZA, G. da S. Introdução aos modelos de regressão linear e nãolinear. Brasília, DF, Embrapa-SPI, 998.

STATISTICAL ANALYSIS SYSTEM INSTITUTE. SAS user's guide. Statistical edition. Cary: SAS institute, 1991.745 p.

STERN, M.D.; SATTER, L.D. Evaluation of nitrogen solubility and the dacron bag techniques as methods for estimating protein degradation in the rumen. Journal of Animal Science, Champaign, v. 58, n. 3, p. 714-724, Mar., 1984.

VIEIRA, R. A. M. Modelos matemáticos para estimativa de parâmetros da cinética de degradação do capim elefante (Pennisetum purpureum, Schum., cv. Mineiro) em diferentes idades de corte. 1995. 88 p. Dissertação (Mestrado) - Universidade Federal de Viçosa, 1995.

WALDO, D. R., SMITH, L. W., COX, L. E. Model of cellulose disappearance from the rumen. J. Dairy Sci. v. 55, n. 1, 1972. 